\title{
Relationship of Principal Leadership Style, Teacher's Work Motivation, School Supervisor's Supervision of Teacher's Learning Quality at Senior High School 1 Binjai Langkat
}

\author{
Sri Ramadhani \\ Universitas Negeri Medan \\ North Sumatera, Indonesia
}

\begin{abstract}
The purpose of this research is to see the relationship of Principal Leadership Style, Teacher Work Motivation, Supervision of School Supervisor to Teacher Learning Quality of SMA Negeri 2 Kabupaten Langkat, North Sumatera. In this study taken 48 people as a sample with proportional random sampling technique. Data were analyzed by using simple regression test. The results of this study indicate that: (1) There is a positive and significant relationship between the principal leadership style and the quality of teacher learning; (2) There is a positive and significant correlation between teacher work motivation and teacher learning quality; (3) There is a positive and significant correlation between supervision of school supervisor and teacher learning quality; (4) There is a positive and significant relationship together between the Principal Leadership Style, Teacher Work Motivation, Supervision of school supervisors with the quality of teacher learning.
\end{abstract}

Key Words: Principal Leadership Style, Teacher Work Motivation, Supervision of School Supervisor, and Teacher Learning Quality.

\section{INTRODUCTION}

The teacher is an important element in learning activities. According Djamarah (2015: 280) The teacher is someone who gives knowledge to students or professional staff who can make students to plan, analyze and conclude the problems faced. While in the opinion of Sofian Amri (2013: 30) identifies the role of the teacher, namely as: corrector, inspirator, informator, organizer, motivator, initiator, facilitator, mentor, demonstrator, class manager, mediator, supervisor and evaluator. As in Government Regulation Number 19 of 2005 Article 20, that teachers are expected to develop learning materials. What is meant is that the effort to improve the quality of learning is the role of all parties involved in the school.

In an effort to produce quality education in schools, many factors or components are involved. Schoolis one complex and unique organization, so in its implementation requires high coordination with all its components. The principal as the leader directly is an examplereal in the work activities of subordinates. Headschools that are diligent, careful, caring for subordinates, will be different from leadershipwhich is indifferent, less communicative especially arrogant with the school community.

Leadership style is a characteristic of a person to influence other people or organizations, so that others want and are able to move and emulate their personal attitudes and attitudes towards achieving goals. Subordinates as an important element involved in achieving goals have differences in ability, needs and personality, so that the approach taken by the leader is adjusted to the maturity level of the subordinates. O ne a leader who has one type can adapt to the situation encountered in implementing leadership. According to Danim (2012: 212214) "there are several types of leadership: 1) autocratic leaders, 2) democratic leaders, 3) permissive leaders". A professional leader is an 'artist' in leading. Art is the fruit of personal creations that others may not have. Therefore, art in leadership is different for everyone. The role of school principals is very important in mobilizing, and harmonizing all educational resources available in schools and using them as needed. That is, the leadership of the principal is one of the factors that can realize the vision, mission, goals and objectives of the school through programs that are planned and phased.

The quality of teacher learning is closely related to the work motivation of a teacher / educator / teacher. Motivation is an important part of every activity, without motivation there is no real activity. If the employee (which is meant here the teacher / educator / teacher) has a positive motivation, he will show interest, have attention, and responsibility for his duties so that their performance increases ... and vice versa if motivation is negative then his interest in the activity weakens even there is no. Like the opinion of E.Mulyasa (2003: 120) that motivation is needed in activities that are directly related to performance improvement. The ideal work motivation of the teacher is something that encourages a teacher to carry out or take action and complete tasks well as a teacher's responsibility to achieve certain goals. In this case the teacher must always 
be ready to develop themselves following the times with continuous learning methods.

The ability of a teacher is also an influence in improving the quality of school services which leads to the quality of learning. In connection with efforts to improve the quality of learning from the four basic competencies that must be possessed by a teacher, the contribution of supervision of supervisors and principals is thought to determine the quality of teacher learning through a control system in the form of coaching, development, research and assessment conducted by the school supervisor called supervision of school supervisors. But the phenomenon that often occurs with supervision of school supervisors only plays a formal role. Lack of coaches given to educators / teachers in improving professionalism is often overlooked. And the presence of unscheduled school supervision supervisors.However, on the contrary, what is often done by supervision of school supervisors only focuses on the results of school work and teachers. This is also a finding that will be seen in this study.

The Indonesian government has a high commitment in improving the quality of national education. Whereas what happens in the field there are still many shortcomings in its implementation. One of them was the reluctance of the school principal in making school policies at Binjai 1 Public High School Langkat, limited creativity and innovative teachers due to the rules that exist in the local government. The principal tends to carry out external activities, the development sciences in teaching are sometimes less socialized to the teachers at Senior High School 1 Langkat Binjai. In school organizations, principals are required to display a leadership that is able to create a conducive work climate, while teachers are required to have high-level motivation, have competencies that are ultimately able to work professionally. The phenomenon of many teachers at Senior High School 1 Langkat Binjai. has low achievement motivation, this is indicated by the presence of teachers who do not make learning tools and the teacher does not have the ability to develop learning syllabi. Teachers tend to pursue a certificate in professional training carried out by relevant agencies. This causes teachers to carry out learning and teaching activities without clear planning so that this will affect the quality of school learning. From the data obtained by the author empirically, it is deemed necessary to have scientific research to prove all the gaps between expectations and realities that occur in the field. This encourages the proof of the relationship of several roles and aspects of the school equipment with the title of the study "The relationship between the leadership style of the principal, the work motivation of the teacher, supervision of the school supervisor on the quality of teacher learning at Senior High School 1 Langkat Binjai.

\section{RESEARCH METHOD}

This study deals with the relationships between various variables, testing hypotheses. The data collection used was a questionnaire. The research data consisted of the first three independent variables were the principal's leadership style (X_1), the second variable was the teacher's work motivation (X_2), and the third variable was supervisory supervision (X_3), while the dependent variable was the quality of teacher learning (Y). The design of this study uses quantitative research with an ex-post facto research approach .

Determination of the number of samples with a significance level of $95 \%$ (Sugiyono, 2009) from the table found that all teachers in high school 1 Binjai Langkat has 53 people. Then the number of samples taken with a significance level of $95 \%$ or a level of error of 5\% is as many as 48 people.

Data was collected through questionnaires or questionnaires to teachers randomly. The scale used in this study is the Likert scale with the choice of answers SS, S, N, TS, STS with a score of 1 to 5 forunfavorable questions and scores of 5 to 1 for favorable questions. To test the third hypothesis the hypothesis is used simple regression analysis techniques.

\section{RESULTS AND DISCUSSION}

In this study the characteristics of each variable can be seen from the table below which is presented in the form of the highest score, lowest score, average price, standard deviation, variance, median, mode, and categorization of each variable studied. The following table. 1:

TABLE 1. Statistical summary of the variables of the principal's leadership style, teacher's work motivation, supervision of school supervisors, and the quality of teacherteacher learning in at Senior High School 1 Langkat Binjai.

\begin{tabular}{|l|r|r|r|r|}
\hline Statistik & \multicolumn{1}{|c|}{$\mathrm{X}_{1}$} & \multicolumn{1}{c|}{$\mathrm{X}_{2}$} & \multicolumn{1}{c|}{$\mathrm{X}_{3}$} & \multicolumn{1}{c|}{$\mathrm{Y}$} \\
\hline Mean & 167,98 & 147,00 & 142,54 & 175,50 \\
\hline Median & 167,00 & 148,50 & 143,00 & 176,00 \\
\hline Mode & 162 & 154 & 143 & 176 \\
\hline SD & 16,08 & 12,09 & 15,720 & 11,88 \\
\hline Var & 258,78 & 146,21 & 247,10 & 141,23 \\
\hline Range & 65 & 58 & 81 & 53 \\
\hline Min & 128 & 112 & 104 & 147 \\
\hline Max & 193 & 170 & 185 & 200 \\
\hline Jumlah & 8063 & 7056 & 6842 & 8424 \\
\hline
\end{tabular}

$\mathrm{X}_{1}$ : Principal style of leadership

$\mathrm{X}_{2}$ : Teacher's Work Motivation

$\mathrm{X}_{3}$ : Supervision of School Supervisors

Y: Learning Quality

From the results of data analysis, it was found that there was a significant relationship between the principal's leadership style and the quality of teacher learning with a contribution of $25.9 \%$. There is a significant relationship between teacher work motivation and the quality of teacher learning with a contribution of $28 \%$. There is a significant relationship between supervision of the quality of teacher learning with a contribution of $37.9 \%$. There is a significant 
relationship between leadership style, teacher morale, supervisor supervisors simultaneously on the quality of teacher learning with contribution of $54.4 \%$.

From the results of the data analysis above, the research hypothesis is the same as the results of the study. The good quality of teacher learning at Senior High School 1 Langkat Binjai. Due to precisely the leadership style of the principal, the motivation of the teacher, the supervision of the school supervisor. The learning process takes place in certain situations, meaning that learning only occurs in certain situations: namely, the existence of potential leanners and learning situations that have strong motivation. Sadia (2003: 6).

The principal's leadership style can be illustrated from the determination of work procedures for teachers and other school support devices because the principal has a very important role in mobilizing, and harmonizing all the educational resources available at school and using it as needed. Wahyudi (2012: 123) states that: The leadership style is applied to the level of maturity or maturity (mature) maturity of subordinates and the goals to be achieved. Subordinates as an important element involved in achieving goals have differences in ability, needs and personality, so that the approach taken by the leader is adjusted to the maturity level of the subordinates.

Sudarwan Danim (2011: 121) states that teacher motivation contains at least six essential elements. First, the objectives to be achieved in the learning process. Second, personal spirit or obsession to achieve goals. Third, endless willingness to realize ideals and hopes for high-level achievements. Fourth, the absence of despair or stopping before the goal is achieved. Fifth, the spirit to develop yourself.Sixth, various creative processes, innovation, and alternatives. Based on the above theory, the teacher's work motivation is also born from within the individual which includes: interests, attitudes towards self, work and work situation, individual needs, abilities or competencies, knowledge of work, emotions, moods, feelings of beliefs and values. Factors of work (external) include: salary received, school policies, supervision, relationships between people, work conditions, organizational culture, giving recognition of achievements, level orthe amount of responsibility given, satisfaction from work.

Bafadal (1992) refers to the opinions of Alfonso (1981), Firth, and Neville, emphasizing that in the implementation of teaching supervision there are three key concepts (key), namely: First, teaching supervision must directly influence and develop teacher behavior in managing the teaching and learning process. Second, the behavior of supervisors (school supervisors) in helping teachers develop their abilities must be designed optimally, so that it is clear when to start and when the development program ends. Third, the ultimate goal of teaching supervision is that teachers are increasingly able to facilitate learning activities for their students. Based on the explanation above, it is clear that with the effective principals leadership behavior, the quality of school supervisor supervision, and balanced with the high morale of the teacher, the quality of teacher learning can be optimized and the desired goals will be achieved.

The quality of teacher learning at Binjai Langkat High School 1 school this has an effect on all school organization devices. School policies that are used as autonomy in education also have an important role in the development of school quality as well as the objectives of national education. As contained in Law No. 22 of 1999 and Law No. 32 of 2004 concerning regions has broad and deep authority to manage their education.

\section{CONCLUSION}

From the results of the research and discussion it can be concluded that the three variables have an effect on the quality of teacher learning at Senior High School 1 Langkat Binjai. And proven the biggest contribution of independent variables from the results of data analysis in a study entitled "The Relationship between Principal Leadership Style, Teacher's Work Motivation, Supervision of School Supervisors at Senior High School 1 Langkat Binjai. is supervision of school supervisors.

As a reference material to continue to improve the quality of teacher learning at Senior High School 1 Langkat Binjai schools are: First, the principal can play a role through the implementation of the lead style as an evaluator and supervisor with the aim of improving human resources (teachers and other support staff) and infrastructure and facilities schools that also affect the process of teaching and learning activities. If these two things are going well then this will improve the quality of the Senior High School 1 Langkat Binjai. Second, teachers must always have strong motivation to improve the quality of teaching. Third, supervisors should supervise schools should have more power than the ability of teachers themselves. With a focus on coaching in improving teacher professionalism.

\section{REFERENCES}

[1] Ace Suryadi, 1993. Analisis Kebijakan Pendidikan. Bandung : PT Remaja Ros-dakarya.

[2] Amiruddin, 2006. Manajemen Pengawasan Pendidikan. Bandung: Quantum Teaching

[3] Arikunto, Suharsimi,1998. Prosedur Penelitian. Yogyakarta: Rineka Cipta.

[4] Bafadal, Ibrahim, 1992. Supervisi Pengajaran Teori dan Aplikasinya Dalam Mem-bina Profesional Guru. Jakarta : Bumi Aksara

[5] Depdagri, 2006. Pendidikan dan Pelatihan Pengawas Sekolah, Jakarta: Badan Pendidikan Dan Latihan Depdagri

[6] Hadi,Sutrisno, 2000, Statistik. Yogyakarta : Andi Affset

[7] Hartati Farida, Tri, 2014. Peran Motivasi Kerja Guru terhadap Kinerja Guru Taman Kanak- Kanak Aisyiyah Pembina Piyungan Bantul. Yogyakarta

[8] Kartini Kartono, 2001. Pemimpin dan Kepemimpinan, Jakarta: PT. Raja Grafindo Persada.

[9] Mulyasa, E. (2013). Manajemen dan Kepemimpinan Kepala Sekolah. Jakarta: PT. Bumi Aksara.

[10] Nurbaya, Siti (2015). Gaya Kepemimpinan Kepala Sekolah dalam Meningkatkan Kinerja Guru pada SD Negeri Lambaro Angan, Aceh. 
[11] Piet Suhertian, 2006, Konsep Dasar dan Tehnik Supervisi Pendidikan, Jakarta : Rineka Cipta

[12] Undang - Undang Republik Indonesia Nomor 22 Tahun 199 tentang Pemerintahan daerah

[13] Undang - Undang Republik Indonesia Nomor 32 Tahun 2004 tentang pemerintahan daerah 